\title{
Minors protest activity in the urban environment as a result of the impact of Internet technologies
}

\author{
Elena Shestakova ${ }^{1, *}$ \\ ${ }^{1}$ The Center of Temporary Isolation for Juvenile Delinquents UMVD of Russian Federation in \\ Tyumen District, Kremlevskayast., 35, Tyumen, 625049, Russia
}

\begin{abstract}
In the modern period, the minors' involvement in illegal activities via Internet technologies is becoming an instrument for political propaganda and agitation of many people, including minors. This is a phenomenon of modern period of social life. The participation of minors in unauthorized protests, as an exclusively urban phenomenon, causes particular attention, since it is accompanied by a large public response and predetermines the development of deviant attitudes of minors. Objectives of the study: an attempt to identify the protest potential of minors in some regions of the Ural Federal District in an urban environment; determining the degree of influence of Internet technologies on the involvement of minors in protest activities. More than half of the respondents are facing political agitation in social networks; only $4-13 \%$ of minors feel the impact on formation of public position via the Internet; protest potential of minors can be estimated at $22 \%$ in the Tyumen Region, $14 \%$ in the Khanty-Mansi Autonomous Area, and $8 \%$ in the Yamal-Nenets Autonomous Area. The protest activity in regions under study in return for remuneration increases. Ratio of surveyed participants indicating that they have faced with political campaign via internet technologies $(50-60 \%)$ and ratio of participants who have not faced $(4-13 \%)$ could signal to the indirect impact.
\end{abstract}

\section{Introduction}

Scientific and technological progress predetermines nowadays the emergence of new phenomena of social life, requiring increased attention from the state, in particular, phenomenon of active involvement of minors in illegal activities via Internet technologies, which is one of the most dangerous trends of our time. A distinctive feature of this phenomenon is the minimum amount of costs and efforts to perform these actions, given that almost every teenager has access to the Internet.

Socially dangerous information, network aggression (cyber-bullying), fraud, theft of personal data, criminal information about potential victims of planned crimes are being actively distributed on the Internet, and special criminal communities are being created in social networks (hackers, distributors of pornography, fraudsters etc.). In the modern

* Corresponding author: Shestakova.e@yandex.ru 
period, the Internet objectively becomes an instrument for political propaganda and agitation of political views, including among minors [1-3].

Over the past five years, we have increasingly heard and observed information about the participation of minors from major Russian cities in numerous protest actions organized by so-called opposition representatives, such as Alexei Navalny, Vyacheslav Maltsev, Sergey Mitrokhin et al. Mass participation of minors in protest actions is becoming ubiquitous.

On March 26, 2017, an uncoordinated protest rally was held in Moscow, organized by the non-profit organization Anti-Corruption Foundation, led by video blogger Alexei Navalny. In social networks, this action was immediately described as a "school riot", due to the participation in the rally of a large number of minors, schoolchildren and students. It was noted not only by Russian researchers, but also by foreign journalists. According to the General Directorate of the Ministry of Internal Affairs of Russia for the city of Moscow, 78 thousand people took part in an unauthorized rally on March 26. Unauthorized actions on this day were held not only in Moscow, but in such cities as: Saransk, Yekaterinburg, Chelyabinsk, Volgograd, Nizhny Novgorod, Samara and others. According to various human rights centers operating in the territory of Russian Federation, over 1,500 thousand people were detained in the cities of Russia.

A threatening trend is the involvement of adolescents in protest actions of an extremist nature, with the aim of provoking riots. So, on October 19, 2017 in the city of Yaroslavl six underage supporters of the "Art-training" movement were detained, the organizer of this action Vyacheslav Maltsev constantly publishes posts in social networks calling for regime change. In the Moscow region, representatives of the movement planned to perform on November 4-5, 2017 resonant extremist actions in form of arson of administrative buildings using incendiary mixtures and attacks on police officers [4-6].

The current government is seriously concerned about the protest activity of minors, politicians are in favor of prohibiting the participation of minors in unauthorized political and other actions, and in December 2018 administrative responsibility was introduced for involving minors in participating in unauthorized actions.

The increased protest activity of minors is often associated with active use of Internet technologies, which is not accidental. According to research of the Internet Development Foundation, in five years the number of adolescents who have more than 100 friends in social networks has almost doubled. At the moment, the circle of "friends" of every second 15-16-year-old boy or girl, and 43\% of 13-14-year-old adolescents is more than 100 people, becoming equivalent to the number of social relations of an adult.

Obviously, representatives of Russian opposition have chosen fertile ground to attract adolescents and young people to their supporters. The current opposition is mastering the "second profession" of video bloggers everywhere. Speeches against corruption on March 26 were broadcast live on the Internet on the portal "Navalnov-life", the underage participants of the action themselves took pleasure in making "selfies" and video broadcasts, actively using popular messengers, which is the main means of communication for today's youth. In social networks there was "very timely" published a film by A. Navalny under the title "He's not Dimon to You", which allegedly exposes the corrupt component of activities of Russian Prime Minister D. Medvedev.

The analysis of this phenomenon is one of the most important aspects of studying the protest potential of minors and the prevention of public conflicts [7].

The fact of the minors' participation in protest rallies in major metropolitan cities is indisputable, but at the same time the protest potential and the increasing protest activity of (in most cases unauthorized) minors in the urban environment has not been investigated.

The purpose of this article is to study theoretical assumptions about the impact of Internet technologies on teenagers; in addition, we have attempted to identify the protest potential of minors in some regions of the Urals Federal District in an urban environment, 
and to determine the presence or absence of Internet technologies impact on the involvement of minors in protest activities at the regional level.

In this article, we consider Internet technologies as a set of modern electronic technical means and software, as well as the organization, forms and methods of their application in information work aimed at using information resources in various areas of human activity.

Protest potential, in our opinion, is the tendency of citizens to participate in protest actions under certain conditions, and protest activity means involvement of citizens in various forms of protest actions [8-13].

\section{Methods}

The German researcher Friedrich Tenbruck noted: "The phenomenon of modern youth is the result of conscious social policy, deliberate social action, rather than spontaneous social development".

Youth participation in protest near-political actions was already clearly manifested in student movements during the post-reform period of Russian Empire in the late 19th and early 20 th centuries.

In the 60 s of the 19 th century, students and young people who expressed dissatisfaction with the existing system, denying religion and generally accepted norms of morality and ethics, were called nihilists. Characteristics of the main characters of the I.S. Turgenev's novel "Fathers and Sons" (Evgeny Bazarov) and the F.M. Dostoevsky's novel "The Demons" (Peter Verkhovensky) clearly demonstrate a portrait of youth of those time.

Political propaganda was at that time carried out by political transformation programs. Thus, in 1861, the program "Towards the Young Generation" appeared in Russia. It criticized the general policy of the government. Young people were called for revolutionary uprisings, promotion of revolutionary ideas among the people and the army, and had a great influence on the democratic students. In the same year, 1861, one of the first student protest unrest occurred, caused by the increased supervision of students. In 1862, one of the first proclamations of an extremist character "Young Russia" came out, which called for an immediate bloody and inexorable revolution. Among the followers of student revolts were Ivan Kalyaev, expelled from St. Petersburg University, a member of the Union of Struggle for the Emancipation of the Working Class, and the murderer of Grand Duke Sergei Alexandrovich Romanov; Boris Savinkov, one of the leaders of the Combat Organization of the Social Revolutionaries, accomplice in the murder of the Minister of Internal Affairs Pleve, the author of the story-biography "Memoirs of a Terrorist".

A.I. Spiridovich described the first period of the student protest movement as follows: "The student unrest of 1899-1901 served as the beginning of the social movement that, growing, gradually captured more and more new groups of the population, revolutionary resulting in the first revolution 1905, brought constitution to Russia".

In modern times, scientists point to the direct dependence of brain activity on social networks. Thus, neurosurgeon scientists under the guidance of Dr. Lauren Sherman from the University of California (USA), using magnetic resonance imaging, conducted a study of 32 teenagers who have accounts on the social network Instagram. As a result, scientists have concluded that the brain activity, responsible for the "pleasure centers" increases significantly when adolescents look at their photos and posts, marked by a large number of "likes". Positive feedback on photos posted (in form of "likes") tells teenagers that their friends appreciate the material they post. This feeling intoxicates minors, and the more "likes" they get for one photo, the more photos they post in the future, regardless of content of photo or post.

Specialists of the Department of Psychology at Loyola Marymount University (Los Angeles, USA) concluded that social networks and the use of alcoholic beverages are 
directly connected. The study involved 412 underage first-year university students. The study was conducted in two stages within half a year. Scientists came to the following results: both males and girls significantly increased their consumption of alcoholic beverages in the second semester. The number of posts related to alcohol in their social networks has also increased significantly. These posts were seen by other students, forcing them to consider drinking alcohol as an important part of their college life, which provoked them to drink alcohol. In addition, the presence of various filters on social networks also allows people to decorate photos, making alcohol more attractive, thereby eliminating ethical problems. The researchers concluded that what students see on social networks may affect their attitudes towards drinking.

In 2012, Wilhelm Hofmann and his colleagues from the Chicago School of Business (USA) came to the conclusion that social network addiction is much stronger than alcohol and smoking addiction. Scientists investigated 205 people, and as a result they came to the conclusion that the highest intensity of the "weak will" was demonstrated by the subjects with respect to social networks, despite the fact that everyone tried to resist. It is noteworthy that it was much easier for the subjects to overcome their desire to play sports, go shopping, drink alcohol, coffee or smoke. As an explanation, it is assumed that cigarettes and alcohol are harmful and require material costs, whereas social networks are considered harmless, therefore, refusal of self-control in using social networks is not considered dangerous.

In August 2016, an article by Dr. Nicholas Kardaras was published in the New York Post that suggested that digital tools affect the frontal cortex of the brain - which controls executive activity, including impulse control as well as cocaine does. "The healthy development of children involves social interaction, creative games and interaction with the real, natural world. Unfortunately, the exciting world of screens blurs and hinders these development processes.

Development of the main directions of preventive activities of the bodies and institutions of the prevention system, focused on the prevention of crime and juvenile delinquency, continues to be one of the most important tasks of the state. Existing theoretical and regulatory gaps are filled by accumulation of knowledge in the framework of criminological and other studies on the patterns and trends of deviant behavior of minors. This led to the choice of general scientific and private scientific methods of cognition (observation, analysis, synthesis, analogy, hypothetical, system-structural, comparative legal methods, content analysis of the press and Internet resources).

The article is based on a survey of 95 minors in the cities of the Tyumen Region, the Khanty-Mansiysk Autonomous Area-Ugra, and the Yamalo-Nenets Autonomous Area.

\section{Results}

Literature review on the degree of influence of Internet technologies on the younger generation suggests its direct impact. We can agree with researchers who believe that social network addiction is growing rapidly. Number of users increases from year to year as well as age range becomes more various.

In order to study the protest potential of minors at the regional level and the impact of Internet technologies on the level of protest activity of minors, we conducted a survey of 95 minors in three regions of the Ural Federal District (tabl.1)

According to a survey of minors, almost $100 \%$ of respondents have 1, 2 or more accounts on social networks. Basically, Internet is used by adolescents for entertainment purposes (computer network games, watching entertainment videos, movies, etc.), as well as for communication with friends. If earlier teenagers talked on the street, now the Internet has remained a platform for communicating and realizing their ambitions, since children 
cannot do it either at home, or in school groups, or in companies of friends. By their actions, they are trying to attract attention to themselves, trying to find their place in life and assert themselves among their peers.

Table 1. Internet technologies on the level of protest activity of minors.

\begin{tabular}{|l|c|c|c|c|c|c|c|c|}
\hline \multirow{2}{*}{ Region } & Total & Male & Female & $\begin{array}{c}14- \\
15 \\
\text { y.o. }\end{array}$ & $\begin{array}{c}16- \\
17 \\
\text { y.o. }\end{array}$ & $\begin{array}{c}\text { Incomplete } \\
\text { secondary }\end{array}$ & Secondary & $\begin{array}{c}\text { Specialized } \\
\text { secondary }\end{array}$ \\
\cline { 2 - 9 } & & $83 \%$ & $17 \%$ & $56 \%$ & $43 \%$ & $57 \%$ & $32 \%$ & $11 \%$ \\
\hline $\begin{array}{l}\text { Tyumen } \\
\text { region }\end{array}$ & 37 & $85 \%$ & $15 \%$ & $53 \%$ & $47 \%$ & $62 \%$ & $32 \%$ & $6 \%$ \\
\hline $\begin{array}{l}\text { Khanty- } \\
\begin{array}{l}\text { Mansi } \\
\text { Autono } \\
\text { mous } \\
\text { Area }\end{array}\end{array}$ & 34 & $80 \%$ & $20 \%$ & $52 \%$ & $48 \%$ & $68 \%$ & $24 \%$ & $8 \%$ \\
Ugra & & & & & & & & \\
\hline $\begin{array}{l}\text { Yamal- } \\
\text { Nenets } \\
\text { Autono } \\
\text { mous } \\
\text { Area }\end{array}$ & 25 & $80 \%$ & & & & & & \\
\hline
\end{tabular}

Table 2. Internet activity according to purposes and susceptibility to political agitation in social networks.

\begin{tabular}{|c|c|c|c|c|c|c|}
\hline \multicolumn{3}{|c|}{ Indicator } & Gr. & $\begin{array}{l}\text { Tyumen } \\
\text { region }\end{array}$ & $\begin{array}{c}\text { Khanty-Mansi } \\
\text { Autonomous } \\
\text { Area-Ugra }\end{array}$ & $\begin{array}{c}\text { Yamal-Nenets } \\
\text { Autonomous } \\
\text { Area }\end{array}$ \\
\hline \multicolumn{3}{|c|}{1 account in social networks } & 1 & $27 \%$ & $32 \%$ & $28 \%$ \\
\hline \multicolumn{3}{|c|}{2 accounts and more in social networks } & 2 & $73 \%$ & $68 \%$ & $64 \%$ \\
\hline \multicolumn{3}{|c|}{ Reason for using (by priority) } & 3 & & & \\
\hline \multirow{5}{*}{$\begin{array}{l}\stackrel{\ddot{\theta} 0}{\Xi} \\
\stackrel{\Xi}{\Xi} \\
\stackrel{0}{0} \\
\Xi\end{array}$} & \multicolumn{2}{|c|}{ Entertaining content } & 4 & $52 \%$ & $47 \%$ & $52 \%$ \\
\hline & \multicolumn{2}{|c|}{ Communication with friends } & 5 & $40 \%$ & $41 \%$ & $36 \%$ \\
\hline & \multicolumn{2}{|c|}{ Education } & 6 & $4 \%$ & $6 \%$ & $8 \%$ \\
\hline & \multicolumn{2}{|c|}{ News, policy etc. } & 7 & $2 \%$ & $3 \%$ & $4 \%$ \\
\hline & \multicolumn{2}{|c|}{ Other } & 8 & $2 \%$ & $3 \%$ & $0 \%$ \\
\hline \multicolumn{3}{|c|}{$\begin{array}{l}\text { Faced with political agitation in social } \\
\text { networks }\end{array}$} & 9 & $59 \%$ & $61 \%$ & $52 \%$ \\
\hline \multirow{3}{*}{\multicolumn{2}{|c|}{$\begin{array}{ll}\text { Subjective } & \\
\text { attitude } & \text { to } \\
\text { political } & \\
\text { agitation } & \\
\text { social } & \\
\text { networks } & \\
\text { (from gr. 3) } & \end{array}$}} & positive & 10 & $27 \%$ & $26 \%$ & $20 \%$ \\
\hline & & neutral & 11 & $32 \%$ & $35 \%$ & $32 \%$ \\
\hline & & negative & 12 & $0 \%$ & $0 \%$ & $0 \%$ \\
\hline \multicolumn{3}{|c|}{$\begin{array}{l}\text { Did you feel an impact on public } \\
\text { position through the internet }\end{array}$} & 13 & $13 \%$ & $9 \%$ & $4 \%$ \\
\hline \multicolumn{3}{|c|}{$\begin{array}{l}\text { Did you see direct calls to participation } \\
\text { in unauthorized protests }\end{array}$} & 14 & $5 \%$ & $3 \%$ & $0 \%$ \\
\hline
\end{tabular}

Polices, news are popular among $2-4 \%$ of respondents in social networks while political agitations are met more than by half of minor respondents. From $20 \%$ respondents in Yamal-Nenets Autonomous Area to $27 \%$ in Tyumen region demonstrate positive attitude towards political agitation in social networks. At present, political agitation is presented on 
the network, for example, in the form of Internet memes, the use of which greatly enhances their political potential, since the visual picture is easier perceived and affects the recipient's subconscious, have a simple humorous background, which greatly simplifies the perception of adolescents and can cause positive emotions. Only 13\% of minors in the cities of the Tyumen region, 9 in the Khanty-Mansi Autonomous Area-Ugra and 4\% in the YamaloNenets Autonomous Area, feel the impact on formation of a public or political position via the Internet, and there are practically no direct calls for participation in protest actions. At the same time, ratio of people who mark manifestations of political agitation via Internet technologies $(50-60 \%)$ and the proportion of those who feel a direct impact on the formation of their own public or political position (4-13\%) may indicate an indirect (hidden) influence on formation of installations through accessible digital tools for understanding and perception of young people.

Table 3. Proportion of minors who are ready to participate in protest action.

\begin{tabular}{|l|c|c|c|}
\hline \multicolumn{1}{|c|}{ Region } & $\begin{array}{c}\text { Ready to participate } \\
\text { in protest action }\end{array}$ & $\begin{array}{c}\text { Ready to participate } \\
\text { in unauthorized } \\
\text { protest action }\end{array}$ & $\begin{array}{c}\text { Ready to participate } \\
\text { in protest action for } \\
\text { payment }\end{array}$ \\
\hline Tyumen region & $22 \%$ & $19 \%$ & $30 \%$ \\
\hline $\begin{array}{l}\text { Khanty-Mansi } \\
\text { Autonomous Area - } \\
\text { Ugra }\end{array}$ & $14 \%$ & $12 \%$ & $24 \%$ \\
\hline $\begin{array}{l}\text { Yamal-Nenets } \\
\text { Autonomous Area }\end{array}$ & $8 \%$ & $8 \%$ & $16 \%$ \\
\hline
\end{tabular}

If we accept the protest potential of minors in the studied regions, the willingness to participate in protest actions can be estimated at $22 \%$ in the Tyumen region, $14 \%$ in the Khanty-Mansi Autonomous Area-Ugra and 8\% in the Yamal-Nenets Autonomous Area, which shows that the protest potential of minors in the Tyumen region is much higher than in two other regions. This can be explained by the geographical location of the regions, the population density, the level of social and economic well-being of the regions, as well as the involvement of the population in near-political processes.

Willingness to participate in unauthorized protest rallies is expressed by practically the same share of people willing ( $19 \% / 12 \%$ and $8 \%$, respectively), which is explained by the fact that the level of education of minors is insufficient for understanding the differences in forms of protest behavior. In addition, a manifestation of readiness to participate in both authorized and unauthorized protests can be explained by the immaturity of adolescent thinking. They consider themselves heroes that at this age they were not afraid to go against the current government, therefore the form of holding the action (authorized or unauthorized) does not have a decisive significance for them.

It is noteworthy that the issue of material incentives for adolescents is largely decisive. Subject to material remuneration in protest actions, $30 \%, 24 \%$ and $16 \%$ are ready to participate, respectively, which demonstrates an increase in the indicators of protest activity by almost 2 times in the studied regions. This indicates that the availability of material resources aimed at remunerating minors can attract more participants to the ranks of those participating in unauthorized protests.

\section{Discussion}

Among adolescents of modern Russians, profound value changes are taking place, which consider it permissible to conduct behavior associated with the violation of social norms in order to achieve success. The manifestation of social activity on display, namely by participating in political actions, may partly be a result of the achievements of information 
technology progress. Undoubtedly, at present we have a whole generation grown on social networks. Many teenagers cannot imagine their lives without the Internet; social networks have changed their perception of the world and their behavior.

Participation of minors and young people in opposition protests in 2017-2018 clearly demonstrated the social portrait of today's youth. The organizers have skillfully used the ambitions of modern adolescents: they can feel like adults, feel that they are not ignored, and finally, they can become famous in social networks by obtaining a large number of "likes" or simply earn money.

As our research has shown, it cannot be unequivocally stated that the protest behavior of adolescents is an extremely negative phenomenon and is the result of the direct impact of Internet technologies. We were convinced that manifestations of political agitation on the Internet are in most cases marked by adolescents and are perceived by them in a positive tint, which can be seen as a mediated (indirect) effect on the formation of the public or political position of adolescents, as well as on making decisions on participation in political activities, including unauthorized. However, given the lack of research on such topics, we cannot argue that the involvement of minors in protest actions in the urban environment by indirect influence through Internet technologies is becoming more intensive and effective, which requires further study and comparative regional analysis of the protest potential of minors.

The greatest danger at the moment is the position of minors who are willing to participate in unauthorized protests, including for material rewards, given that this fact can be used by adults to manipulate the actions of minors, including by engaging in the commission of crimes, which requires consideration in predicting juvenile delinquency and planning preventive work with this category of minors.

\section{Conclusion}

Young people have always been the driving force of revolution. And if a hundred years ago we solved the problem with radical performances of young people, it is quite natural that this problem may arise again, considering that the factors influencing the deviant behavior of adolescents have not disappeared.

Thus, we come to the conclusion that the formation and development of a specific motivational sphere and the social and moral identity of minors requires subsequent scientifically based analysis.

\section{References}

1. A.L. Osipenko, Nauchny vestnik Omskoy akademii MVD Rossii 2, 38-43 (2010)

2. G.U. Soldatova, O.I. Olkina, Children in informational society 2, 24 (2016)

3. O.I. Losenkov, Vestnik Astrakhanskogo gosudarstvennogo tekhnicheskogo universiteta 3, 302-306 (2006)

4. A.B. Volynchuk, S.A. Solovchenkov, Vestnik Vladivostokskogo gosudarstvennogo universiteta econimiki i servisa 1(19), 25-35 (2013)

5. F.H.Y. Tenbruck, Gesellschaftliche Lage oder gesellschaftliches Versagen? Jugend und Gesellschaft (Realitatsbeweltigung, Krisen und Auswege, Stuttgard, 1986)

6. E.K. Rudnitskaya, Revolutionary radicalism in Russia: 12th century (Documental publication, Moscow, 1997)

7. B. Savinkov, Memories of terrorist (Moscow, 2002)

8. A.I. Spiridonovich, Gendarme notes (Kharkov, 1928) 
9. L.E. Sherman, A.A. Payton, L.M. Hernandez, P.M. Greenfield, M. Dapretto, Psychological Science 27, 1027-1035 (2016)

10. S.C. Boyle, J.W. LaBrie, N.M. Froidevaux, Y.D. Witkovic, Addictive Behaviors 57, 21-29 (2016)

11. W. Hofmann, K.D. Vohs, R.F. Baumeister, Psychological Science 23(6), 582-588 (2012)

12. S.V. Kanashina, Politic linguistic 1(61), 69-73 (2017)

13. G.A. Fomchenkova, Vlast 12, 119-123 (2012) 